\title{
Dramatisk sykehistorie forårsaket av uvanlig bakterie
}

\author{
En mann ble innlagt i lokalsykehuset med luftveissymptomer av tre \\ ukers varighet. Det skulle vise seg at han var infisert med en uvanlig \\ bakterie.
}

Se kommentar side 152 og kunnskapsprøve på www.tidsskriftet.no/quiz

\author{
Einar Dale* \\ einar.dale@rikshospitalet.no \\ Lars Heggelund \\ Medisinsk avdeling \\ Sykehuset Buskerud \\ 3004 Drammen

\section{Truls Michael Leegard} \\ Mikrobiologisk institutt \\ Oslo universitetssykehus, Rikshospitalet \\ Helvi Holm Samdal \\ Avdeling for mikrobiologi \\ Sykehuset Buskerud \\ Thor Edvardsen \\ Hjertemedisinsk avdeling \\ Oslo universitetssykehus, Rikshospitalet

\section{Erik Gjertsen} \\ Medisinsk avdeling \\ Sykehuset Buskerud \\ * Nåværende adresse: \\ Kreftklinikken \\ Radiumhospitalet \\ Oslo universitetssykehus, Rikshospitalet \\ 0310 Oslo
}

En 62 år gammel mann ble innlagt i sykehus etter tre uker med økende funksjonsdyspné og radiologiske tegn til hjertesvikt Istuvning og Kerley B-linjer). Bortsett fra hypertensjon, behandlet med losartan og hydroklortiazid, hadde han tidligere stort sett vært frisk. Han hadde kontaktet legevakten to uker tidligere, og det ble da startet antibiotikabehandling med erytromycin mot antatt luftveisinfeksjon. Det var ingen klinisk effekt av denne behandlingen, og medisinen ble seponert dagen før sykehusinnleggelsen.

Pasienten hadde ikke hvile- eller taledyspné. Blodtrykket var 150/59 mm Hg, han hadde regelmessig hjertefrekvens på $105 \mathrm{slag} / \mathrm{min}$, og kroppstemperaturen var $37,5^{\circ} \mathrm{C}$. Ved auskultasjon av hjertet ble det påvist sannsynlig nyoppstått kraftig kombinert systolisk og diastolisk bilyd grad 4, for $\emptyset v r i g$ var det normal organstatus. Blodprøver avdekket moderat forhøyede inflammasjonsmarkører (C-reaktivt protein $90 \mathrm{mg} / \mathrm{l}$, senkningsreaksjon $49 \mathrm{~mm} / \mathrm{t}$, men ingen leukocytose, $7,8 \cdot 10^{9} / \mathrm{l}$, moderat anemi (hemo- globin $10,7 \mathrm{~g} / 100 \mathrm{ml}$, lett forhøyet myokardskademarkør (troponin I 1,39 $\mu \mathrm{g} / \mathrm{l}$ ), men nær normal CK-MB $(6,8 \mu \mathrm{g} / \mathrm{l})$ og biokjemiske holdepunkter for hjertesvikt (pro-brain natriuretisk peptid $611 \mathrm{pmol} / \mathrm{l})$. EKG viste sinusrytme med AV-blokk grad 1, venstre akse, $R$-tap i fremre vegg og tegn til venstre ventrikkel-hypertrofi.

På bakgrunn av akutt hjertesvikt og nyoppstått hjertebilyd fant vakthavende lege indikasjon for ekkokardiografi, som ble utført allerede få timer etter innleggelsen. Venstre ventrikkel var dilatert, med endediastolisk dimensjon på 6,7 cm og endesystolisk dimensjon på 4,7 cm. Ejeksjonsfraksjonen ble estimert til $48 \%$ (nedre normalområde). Slagvolumet var $93 \mathrm{ml}$, og med en hjertefrekvens på 105 slag/min ble minuttvolumet da 9,75 l/min. Aortaklaffen var trikuspid, med en endokardittsuspekt pendulerende vegetasjon på den ikke-koronare klaffen, 0,7 cm $\times 0,9 \mathrm{~cm}$, og en nesten like stor vegetasjon på den høyre koronare klaffen (fig 1, videosnutt 1, videosnutt 2). Det var ingen tegn til abscessdanning. Den ikke-koronare klaffen var nesten totalt destruert, og dette ga opphav til stor aortainsuffisiens, med trykkhalveringstid på 56 ms (fig 2, videosnutt 3, videosnutt 4). Høyre ventrikkel var normal, med en liten trikuspidal insuffisiens. Trikuspidallekkasjegradienten var $47 \mathrm{~mm} \mathrm{Hg}$, og $v$. cava målte $1,7 \mathrm{~cm}$, med noe redusert respiratorisk variasjon. Dette indikerte betydelig grad av pulmonal hypertensjon, med et estimert trykk i det lille kretsløp på om lag $60 \mathrm{~mm} \mathrm{Hg}$. Det ble også påvist en liten til middels mitralinsuffisiens.

I henhold til de modifiserte Dukes kriterier forelå det mulig endokarditt med alvorlig destruksjon av aortaklaffen og påfølgende hjertesvikt (ramme 1) $(1,2)$. Seks sett blodkulturer ble tatt før empirisk antibiotikabehandling i form av penicillin og tobramycin ble iverksatt.

Pasienten hadde ikke vært til tannlege på flere år. Tannlegetilsyn under sykehusoppholdet viste at mulig inngangsport for infek- sjonen var flere områder med periodontitt og tannslitasje ned til pulpa med rotrester.

Dagen etter innleggelsen var blodtrykket sunket til 90/60 mm Hg. Det var ingen tegn til perifer embolisering. Tilstanden ble oppfattet som svært alvorlig, og pasienten ble, under ett døgn etter innleggelse i lokalsykehuset, overflyttet til Rikshospitalet for overvåking med tanke på kirurgisk intervensjon. Koronar angiografi påviste kun veggforandringer. Pasienten hadde på dette tidspunkt akutt hjertesvikt med truende lungeødem pga. destruert aortaklaff. Han ble umiddelbart operert med eksisjon av aortaklaffen og innsetting av mekanisk klaff $10 n-X 23$, On-X Life Technologies, Inc., Austin, TX, USA). Den igangsatte antibiotikabehandlingen ble videreført. Det var et ukomplisert postoperativt forløp, og pasienten ble sendt tilbake til lokalsykehuset tre dager etter hjertekirurgien.

Etter fire døgns inkubasjon ble det påvist vekst i alle seks aerobe blodkulturflasker. Mikroskopi av grampreparat viste små gramnegative, til dels pleomorft fargede staver. Det var samme funn i alle flasker. Ved utsæd vokste bakterien langsomt, og den lot seg ikke sikkert klassifisere med ordinære mikrobiologiske biokjemiske analyser, tilgjengelige agglutinasjonsteknikker eller kommersielle identifikasjonsmetoder. På bakgrunn av kliniske opplysninger samt vekstmønster og utseende i mikroskop mistenkte man en bakterieart tihørende HACEK-gruppen (Haemophilus parainfluenzae, Aggregatibacter aphrophilus (tidligere Haemophilus aphrophilus og Haemophilus paraphrophilus), Aggregatibacter actinomycetemcomitans (tidligere Actinobacillus actinomycetemcomitans), Cardiobacterium hominis, Eikenella corrodens og Kingella kingae). Molekylærbiologisk diagnostikk av blodkulturisolat og fjernet aortaklaff ble utført. Bakteriespesifikk 16S rDNA-sekvensering avdekket meget godt (99\%) samsvar med databasesekvens for Cardiobacterium valvarum i begge prøvematerialer.

Resistensundersøkelser med E-testmetodikk (AB Biodisk, Solna) ble utført ved primærlaboratoriet. Det foreligger ikke internasjonalt standardiserte metoder for resistenstesting av $\mathrm{C}$ valvarum, men ut fra referanser fra $\mathrm{AB}$ Biodisk ble haemophilustestmedium (Oxoid) valgt. Det ble ikke funnet holdepunkter for betalaktamasepro- 


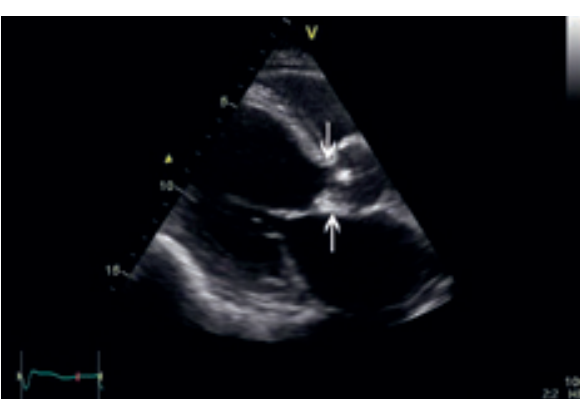

Figur 1 Ekkokardiografi ble utført kort tid etter innleggelsen. Aortaklaffen var trikuspid, med en endokardittsuspekt pendulerende vegetasjon på den ikke-koronare klaffen og en nesten like stor vegetasjon på den høyre koronare klaffen

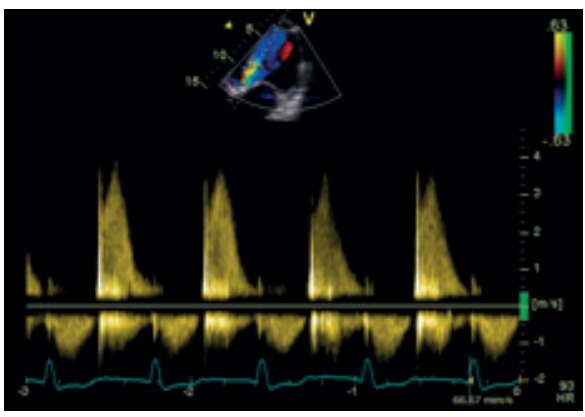

Figur 2 Ifølge ekkokardiografi kort tid etter innleggelsen var det ingen tegn på abscessdanning. Den ikke-koronare klaffen var nesten totalt destruert, og dette ga opphav til stor aortainsuffisiens

duksjon eller annen in vitro-resistens mot undersøkte antibiotika (minimal inhibitory concentration, MIC (mg/l): penicillin 0,004, ampicillin $<0,016$, cefotaksim 0,008 , ceftriakson $<0,016$, gentamycin 0,19 , tobramycin 0,125 , ciprofloksacin 0,008 ).

Ved endokarditt forårsaket av bakterier HACEK-gruppen anbefales vanligvis ampicillin eller 3.-4. generasjons kefalosporin (1). Penicillin + tobramycin ble erstattet med ampicillin + tobramycin, med senere overgang til ceftriakson i monoterapi. Pasienten fikk i alt fem ukers antibiotikabehandling. Den postoperative fasen var ukomplisert uten kliniske eller ekkokardiografiske holdepunkter for dysfunksjonell mekanisk aortaventil eller persisterende hjertesvikt.

\section{Diskusjon}

\section{Mikrobiologisk diagnostikk}

Ved mistanke om endokarditt er adekvat høsting av blodkulturer forut for oppstart av antimikrobiell behandling essensielt. Identifikasjon av type bakterie i blodkultur vil kunne være veiledende for videre antimikrobiell behandling. Kunnskap om aktuell mikrobe vil også kunne gi informasjon om forventet klinisk forløp - spesielt med tanke på behov for akutt kirurgi. Ved høsting av blodkulturer bør det tappes med flere venepunksjoner, f.eks. fra begge armer og ved ulike tidspunkter. Det er ikke avgjørende at høstingen skjer ved frysninger/feber.
Det er spesielt viktig at det mikrobiologiske laboratoriet gjøres kjent med mistanken om endokarditt, slik at blodkulturene kan inkuberes tilstrekkelig lenge og på riktig medium. Dette aktualiseres spesielt med denne kasuistikken, der det var oppvekst av $\mathrm{C}$ valvarum, tilhørende HACEK-gruppen, der dyrkingstiden kan være opptil 5-7 dager $(2,3)$. Så langt vi vet, er C valvarum kun beskrevet som årsak til endokarditt $\mathrm{i}$ fem kasuistikker tidligere, første gang i 2004 (4-8). I en av kasuistikkene er det kliniske forløpet ikke beskrevet (6). Siden bakterien er sjelden, er det ikke utarbeidet standardiserte ordinære mikrobiologiske metoder for eksakt identifikasjon. Etter oppdagelsen av $\mathrm{C}$ valvarum har molekylærbiologisk diagnostikk vært avgjørende for korrekt identifikasjon, slik det var i denne kasuistikken. Dette understreker viktigheten av anvendelse av molekylærbiologiske metoder i mikrobiell diagnostikk der det er uklare resultater ved konvensjonelle metoder. I ytterste konsekvens kan man konkludere med feil bakterie hvis man kun baserer seg på tradisjonell diagnostikk (6).

\section{Antibiotikabehandling ved endokarditt}

Rask igangsetting av antibiotikabehandling med tilstrekkelig behandlingsvarighet er av avgjørende betydning for å unngå destruksjon av den infiserte hjerteklaffen, med påfølgende behov for hjertekirurgi. Endokarditt oppstår i endotel som er skadet, enten pga. høy hastighet på blodstrømmen eller det kan være degenerativ klaffeskade. Vanligvis rammes venstre hjertehalvdel, der det er høyere trykk. Hos narkomane rammes høyre hjertehalvdel oftest. Endotelskade disponerer for fibrinavleiring og blodplateavleiring, som fungerer som vekstmedium for bakteriene, og det dannes vegetasjoner dekket av fibrin. Hjerteklaffene er i utgangspunktet lite vaskularisert. Kroppens immunforsvar med antistoffer og fagocytterende celler har derfor dårlig tilgang til infisert vev, og bakteriene kan vokse relativt fritt.

Ved valg av antibiotika bør flere momenter vektlegges: Type må velges ut fra resistensundersøkelser og måling av minste hemmende konsentrasjon (MIC), medikamentet må ha gode diffusjonsegenskaper i infisert vev, og det må gis i tilstrekkelig høy dose intravenøst. Forut for resistensbestemmelse startes empirisk behandling (vanligvis penicillin og gentamicin) så snart blodkulturer er sikret.

Man har naturlig nok lite erfaring med antibiotikabehandling av endokarditt forårsaket av $\mathrm{C}$ valvarum. I tidligere publiserte kasuistikker har behandlingen variert $(4,5$, $7,8)$. Den nær beslektede $\mathrm{C}$ hominins er vanligvis sensitiv for penicillin, men det er påvist betalaktamaseaktivitet hos disse bakteriene. Derfor anbefaler American Heart Association (1) ceftriakson i 4-6 uker mot C hominis, og man må anta at dette er en effek-

\section{Ramme 1}

Hoved- og bikriterier for diagnosen infeksiøs endokarditt (modifiserte Dukes' kriterier (1)). Diagnosen stilles enten ved minst to hovedkriterier eller ved ett hovedkriterium og tre bikriterier eller ved fem bikriterier. Pasienten har «mulig endokarditt» ved ett hovedkriterium og ett bikriterium eller tre bikriterier. Denne rammen er basert på en tilsvarende fra Sjursen (2) (gjengitt med tillatelse)

\section{Hovedkriterier - mikrobiologi}

- Typiske bakterier i to blodkulturer (Streptococcus viridans, S bovis, Staphylococcus aureus, HACEK-gruppen, enterokokker) med ikke påvist primærfokus

- Persisterende bakteriemi (12 t). Vekst i tre av tre eller i tre av fire blodkulturer

En enkelt blodkultur positiv for Coxiella burnetii eller antifase $1 \mathrm{lgG}$-antistoff titer $>1: 800$

Hovedkriterier - klaffer

- Typiske ekkokardiografiske funn: Oscillerende intrakardial masse på klaffer eller støtteapparat Itransøsofeagal ekkokardiografi anbefalt ved kunstige klaffer og «mulig endokarditt» eller komplisert kjent endokarditt (paravalvulær abscess)]

\section{Abscess}

Ny partiell løsning av klaffeprotese Ny klaffelekkasje løkning eller forandring av kjent bilyd er ikke tilstrekkelig)

\section{Bikriterier}

Predisponerende hjertesykdom eller intravenøst stoffmisbruk

\section{Feber $38^{\circ} \mathrm{C}$}

- Vaskulære funn: Arteriell embolus, mykotisk aneurisme, intracerebral blødning, konjunktival blødning, Roths flekker, petekkier, Janeways lesjoner

Immunfenomen: Glomerulonefritt, Oslers knuter, positiv revmatoid faktor Positive blodkulturer som ikke oppfyller hovedkriteriene lvekst av andre bakterier enn de som er nevnt under hovedkriterier]

tiv strategi også mot $\mathrm{C}$ valvarum pga. disse to mikrobenes nære slektskap. I norske retningslinjer anbefales ampicillin i 4-8 uker med tillegg av gentamicin de første to ukene ved HACEK-endokarditt (9).

\section{Karakteristika}

ved cardiobacteriumendokarditt

Vår pasient hadde en sannsynlig nyoppstått kardial bilyd, funksjonsdyspné og lette infeksjonstegn som viktigste kliniske funn som kunne settes i sammenheng med diagnosen endokarditt. I oversiktsartikler om C 


\section{Ramme 2}

Ekkokardiografiske funn som øker indikasjonen for kirurgi, ifølge Bayer og medarbeidere (14). Oversatt og gjengitt med tillatelse fra Sjursen (2)

Persisterende vegetasjoner etter alvorlig embolisk episode

Store (> $1 \mathrm{~cm}$ i diameter) anteriore mitralklaffvegetasjoner

$\emptyset$ kt vegetasjonsstørrelse etter fire ukers antibiotikaterapi

Akutt mitralinsuffisiens

Klaffeperforasjon eller -ruptur

Periannulær utbredelse av infeksjonen

\section{Ramme 3}

Indikasjon for kirurgi ved endokarditt $(15,16)$. Oversatt og gjengitt med tillatelse fra Sjursen (2)
Hjertesvikt som ikke korrigeres av medikamentell behandling
Mer enn én alvorlig embolus
Infeksjon som ikke responderer tilfredsstillende på antibakterielle midler, spesielt ventilendokarditt Betydelig klaffedysfunksjon
Reseksjon av mykotisk aneurisme Alvorlige ledningsforstyrrelser

hominis er kardial bilyd angitt hos 94-96\%, men dette er også klassisk ved endokarditter forårsaket av andre mikrober $(10,11)$. Et kjennetegn på $\mathrm{C}$ hominis-endokarditt er et snikende eller subakutt forløp med lite feber og allmennsymptomer av lengre varighet forut for sykehusinnleggelsen, til forskjell fra vanligere endokardittpatogener som stafylokokk- eller streptokokkendokarditt. Gjennomsnittlig symptomvarighet for $\mathrm{C}$ hominis-endokarditt var $\mathrm{i}$ to oversiktsartikler angitt til ca. 20 uker $(10,11)$, mens det i oversiktsartikler der man har tatt for seg populasjonsstudier der stafylokokk- og streptokokkendokarditter dominerer, angis 4-6 ukers symptomvarighet $(12,13)$.

Lang sykehistorie forut for oppstart med antbiotika øker risikoen for alvorlig klaffeskade, og $\mathrm{C}$ hominis er forbundet med økt risiko for hjertesvikt sammenliknet med andre HACEK-mikrober (11). Vår pasient hadde en relativt kort sykehistorie på tre uker, altså kortere symptomvarighet enn man kunne forvente. Likevel utviklet han hjertesvikt og ble operasjonstrengende. Det er mulig at infeksjonen hadde vart signifikant lenger enn tre uker.

Aortaklaffen synes å bli rammet oftere ved C hominis-endokarditt (11). Dette ser også ut til å være tilfellet for $\mathrm{C}$ valvarum, $\mathrm{i}$ og med at det $\mathrm{i}$ alle de publiserte kasuistik- kene (inkludert vår) var nødvendig med utskiftning av aortaklaffen $(4,5,7,8)$.

\section{Indikasjon for kirurgi}

Vår pasient hadde destruert aortaklaff og trengte rask kirurgisk intervensjon. En fallgrube ved behandling av venstresidig endokarditt er å undervurdere progrediering av hjertesvikt. Pasientene må overvåkes nøye med henblikk på tegn til sirkulatorisk instabilitet. Det må gjøres regelmessige ekkokardiografiske undersøkelser, og det er foreslått kriterier som øker indikasjonen for kirurgisk intervensjon (ramme 2) (2, 14). Pasienter med vedvarende og ukontrollerbar infeksjon eller tegn på økende hjertesvikt skal overføres til sykehus med hjertekirurgisk kompetanse for vurdering. Systematiske kriterier for akutt kirurgi er tidligere beskrevet (ramme 3) $(2,15,16)$.

I alle de fire tidligere publiserte kasuistikkene med $\mathrm{C}$ valvarum der det kliniske forløpet er gjengitt (i tillegg til vår), måtte pasientene opereres med innsetting av kunstig hjerteklaff. Dette skiller seg tilsynelatende fra et oversiktsmateriale med $\mathrm{C}$ hominis, der kun $40 \%$ (23 av 57) ble operert (10). Man kan spekulere på om $\mathrm{C}$ valvarum har økt virulens sammenliknet med $\mathrm{C}$ hominis til tross for deres genetiske likhet. En annen forklaring kan være at terskelen for hjertekirurgi er senket som følge av klarere retningslinjer (ramme 3).

\section{Tilgang på kardiolog}

Ekkokardiografi er en sentral undersøkelse for å påvise vegetasjoner som følge av endokarditt og i den løpende vurderingen av den sirkulatoriske betydningen av klaffeskade. En fullverdig ekkokardiografisk undersøkelse bør utføres av spesialist i hjertesykdommer, men i Norge varierer det i hvilken grad det er døgnkontinuerlig vaktordning med kardiolog på sykehusene. Ved sykehus uten kardiologisk vaktordning bør man satse på systematisk opplæring av vaktleger i ekkokardiografi, slik at pasienter med mistenkt endokarditt kan få hurtig og adekvat vurdering (17). Vår pasient var heldig, siden vakthavende lege behersket ekkokardiografisk undersøkelse.

\section{Konklusjon}

Langsomtvoksende C valvarum kan forårsake alvorlig endokarditt med et snikende forløp med lite allmennsymptomer og feber. Kasuistikken illustrerer betydningen av moderne molekylærbiologisk diagnostikk ved endokarditt og hvor viktig det er å evaluere pasienten fortløpende, både klinisk og med ekkokardiografi med tanke på hurtig kirurgi.

Pasienten har gitt samtykke til at artikkelen blir publisert.

Oppgitte interessekonflikter: Erik Gjertsen har mottatt honorar/reisestipend fra Novartis, AstraZeneca, Bohringer Ingelheim og Sanofi Aventis. De andre forfatterne har ingen oppgitte interessekonflikter.
Litteratur

1. Baddour LM, Wilson WR, Bayer AS et al. Infective endocarditis: diagnosis, antimicrobial therapy, and management of complications: a statement for healthcare professionals from the Committee on Rheumatic Fever, Endocarditis, and Kawasaki Disease, Council on Cardiovascular Disease in the Young, and the Councils on Clinical Cardiology, Stroke, and Cardiovascular Surgery and Anesthesia, American Heart Association: endorsed by the Infectious Diseases Society of America.. Circulation 2005; 111: e394-434. Rettelse: Circulation 2005; 112: 2373

2. Sjursen $\mathrm{H}$. Antibiotikabehandling ved infeksiøs endokarditt. Tidsskr Nor Lægeforen 2001; 121: $3300-5$.

3. Digranes A. Inkubering og rutiner ved videre arbeid med positive blodkulturer. I: Hermansen NO, Hjetland R, Muller F, red. Blodkultur. Rappor fra strategimøte nr. 16-2002. Oslo: Divisjon for smittevern, Nasjonalt folkehelseinstitutt, 2002: $34-42$.

4. Han XY, Meltzer MC, Woods JT et al. Endocarditis with ruptured cerebral aneurysm caused by Cardiobacterium valvarum sp. nov. J Clin Microbiol 2004; 42: $1590-5$.

5. Hoover SE, Fischer SH, Shaffer R et al. Endocarditis due to a novel Cardiobacterium species. Ann Intern Med 2005; 142: 229-30.

6. Petti CA, Polage CR, Schreckenberger $P$. The role of $16 \mathrm{~S}$ rRNA gene sequencing in identification of microorganisms misidentified by conventional methods J Clin Microbiol 2005. 43: 6123-5.

7. Bothelo E, Gouriet F, Fournier PE et al. Endocard itis caused by Cardiobacterium valvarum. J Clin Microbiol 2006; 44: 657-8.

8. Geissdorfer W, Tandler R, Schlundt C et al. Fatal bioprosthetic aortic valve endocarditis due to Cardiobacterium valvarum. J Clin Microbiol 2007; 45: $2324-6$.

9. Vilberg A, red. Bakteriell endokarditt. I: Norsk legemiddelhåndbok for helsepersonell 2004: 72-6. www.legemiddelhandboka.no (1.8.2009).

10. Walkty A. Cardiobacterium hominis endocarditis: a case report and review of the literature. Can J Infect Dis Med Microbiol 2005; 16: $293-7$.

11. Malani AN, Aronoff DM, Bradley SF et al. Cardiobacterium hominis endocarditis: two cases and a review of the literature. Eur J Clin Microbiol Infect Dis 2006; 25: 587-95.

12. Pelletier LL jr., Petersdorf RG. Infective endocarditis: a review of 125 cases from the University of Washington hospitals, 1963-72. Medicine 1977; 56: $287-313$

13. Sandre RM, Shafran SD. Infective endocarditis: review of 135 cases over 9 years. Clin Infect Dis 1996; 22: 276-86.

14. Bayer AS, Bolger AF, Tauber KA et al. Diagnosis and management of infective endocarditis and its complications. Circulation 1998; 98: 2936-48.

15. D'Agostino RS, Miller DC, Stinson EB et al. Valve replacement in patients with native valve endocarditis: what really determines operative outcome? Ann Thorac Surg 1985; 40: 429-38.

16. Moon MR, Stinson EB, Miller DC. Surgical treatment of endocarditis. Prog Cardiovasc Dis 1997; 40: $239-64$

17. Norsk Cardiologisk Selskap. Indikasjoner for ekkokardiografi. www.hjerte.no/id/152133.0 (1.8.2009).

Manuskriptet ble mottatt 23.12. 2008 og godkjent 24.9. 2009. Medisinsk redaktør Erlend Hem. 